\title{
Covid-19: the crisis of personal protective equipment in the US
}

\author{
Shortages are occurring amid widely varying demand, use, and supply strategies, Douglas Kamerow \\ finds
}

\section{Douglas Kamerow associate editor}

The BMJ

\begin{abstract}
As covid-19 makes its way through the US, in some locations doctors, nurses, and other healthcare workers are facing the frightening prospect of work without personal protective equipment (PPE). A national survey of hospital infection control professionals reported that many medical facilities are nearing the end of their PPE supplies, despite frantic attempts to obtain more. As of 27 March, nearly a third of facilities were almost out of face masks, $13 \%$ had no more plastic face shields, and about $25 \%$ were completely or nearly out of gowns. ${ }^{1}$
\end{abstract}

The mayors of many large and small US cities have also reported PPE shortages. Responding to a national survey, $91 \%$ of 213 mayors said their cities had inadequate supplies of face masks and $88 \%$ said they didn't have enough PPE for their medical and first responder personnel. ${ }^{2}$ The situation has got so bad that in some places, such as San Francisco and New York, medical facilities have asked members of the local community to donate masks they may have bought for their personal use. ${ }^{3}$

\section{Challenges differ across the country}

Many urban hospitals, such as those in New York City, are having difficulty buying supplies to keep up with heightened demand for PPE. Prices have increased and new, sometimes suspect, dealers in protective equipment have appeared out of nowhere, soliciting business at inflated prices. ${ }^{45}$

But in many smaller cities and states where the case burden of covid-19 is lower, hospitals have so far been able to keep up with demand. Carl Schoenberger, who directs the intensive care unit at St Mary's Regional Medical Center in Russellville, Arkansas, a 140 bed hospital in a small city, told The BMJ that his facility currently has enough PPE. Hospital officials there hold a daily covid-19 meeting that includes reports on efforts to obtain new supplies. "We've had PPE from our usual suppliers, other hospitals in our company, the state government, and from new commercial sources," he said. When possible, they also are reusing PPE to decrease demand.

In Michigan, state governor Gretchen Whitmer went on national television on 29 March to ask for supplies, stating that the "dire situation in Detroit is getting worse by the minute. All of our energy needs to be focused on getting PPE."

At the same time, nearby University of Michigan hospitals were employing a range of strategies that allowed them to keep up with demand. Philip Zazove, professor and chair of family medicine at the university, described to The $B M J$ a search for PPE that includes their usual supply sources as well as soliciting donations from businesses and the community. Meanwhile they are working hard to conserve the supplies they have by limiting contact with high risk patients only to the staff who are necessary to their care. "We have also been working with the school of engineering to develop a method to sanitise PPE with ultraviolet radiation so it can be reused safely," he said.

\section{National stockpile}

Many states have stockpiled PPE and other disaster supplies and have begun supplying their own hospitals. There is also a strategic national stockpile (SNS), under the direction of the health and human services secretary in collaboration with the Centers for Disease Control and Prevention. It is divided among multiple secure facilities around the US and contains massive but unspecified amounts of PPE, preloaded on to shipping pallets for quick distribution. ${ }^{7}$ Supplies from the SNS have been released to the states during prior emergencies, including the 2009 H1N1 influenza pandemic and the 2014 Ebola virus disease outbreak.

Many states have already requested supplies from the SNS; some, like Florida, have got all they asked for. Others, like New York and New Jersey, received only a small fraction of their orders. ${ }^{8}$ The federal government has made it clear that there is not enough PPE in the national stockpile to satisfy all demands, and it will be purchasing more supplies to restock.

As the pandemic marches through the US, most hospitals will eventually require larger amounts of PPE, however they obtain it. The need is real and growing. As Larry Hogan, governor of Maryland, said, speaking of doctors and nurses, "They are in danger." The lack of PPE is "the greatest tragedy of this crisis. 
We're pushing to get supplies everywhere we can get them. There simply is not enough."

Douglas Kamerow is senior scholar, Robert Graham centre for policy studies in primary care, professor of family medicine at Georgetown University, and associate editor for The BMJ.

1 Thompson D. Nationwide shortages looming for respirators, masks, gowns: Expert poll. 27 March 2020. https://consumer healthday.com/infectious-disease-information-21/ coronavirus-1008/nationwide-shortages-looming-for-respirators-masks-gowns-expertpoll-756165.html.

2 United States Conference of Mayors. Shortages of covid-19 emergency equipment in US cities: a survey of the nation's mayors. 27 March 2020.www.usmayors.org/issues/covid19/equipment-survey.

3 Ostrov BF. With medical safety gear scarce, the public is stepping up. Kaiser Health News. 23 March 2020. https://khn.org/news/coronavirus-ppe-mask-shortage-donationguide/.

4 Harwell D. Gouged prices, middlemen and medical supply chaos. Washington Post. 28 March 2020. www.washingtonpost.com/business/2020/03/26/gouged-prices-middlemenmedical-supply-chaos-why-governors-are-so-upset-with-trump.
5 Nierenberg A. Where are all the masks? New York Times. 31 March 2020. www.nytimes. com/article/face-masks-coronavirus.html.

6 LeBlanc B. Whitmer 'relieved' by new masks, but situation is 'dire'. Detroit News. 29 March 2020. www.detroitnews.com/story/news/local/michigan/2020/03/29/whitmer-relieved-newmasks-but-situation-detroit-dire/2935300001.

7 Board on Health Sciences Policy. The strategic national stockpile: origin, policy foundations, and federal context. National Academies Press. 24 October 2016. www.nap.edu/catalog/ 23532/the-nations-medical-countermeasure-stockpile-opportunities-to-improve-theefficiency.

8 Olorunnipa T, Dawsey J, Janes C, Stanley-Becker I. Governors plead for medical equipment from federal stockpile plagued by shortages and confusion. Washington Post. 31 March 2020. www.washingtonpost.com/politics/governors-plead-for-medical-equipmentfrom-federal-stockpile-plagued-by-shortages-and-confusion/2020/03/31/18aadda0-728d11ea-87da-77a8136c1a6d story.html.

9 Olivo A, Wiggins O, Schneider GS. Mayors issue order telling Washingtonians to stay home, following directives in Maryland and Virginia. Washington Post. 30 March 2020. www.washingtonpost.com/local/hogan-northam-coronavirus-stay-home-orders/2020/03/ 30/5ł36e146-722f-11ea-85cb-8670579b863d_story.html.

Published by the BMJ Publishing Group Limited. For permission to use (where not already granted under a licence) please go to http://group.bmj.com/group/rights-licensing/ permissions 